\title{
Managing and Containing Displacement after the Cold War: UNHCR and Somali Refugees in Kenya
}

\author{
Jennifer Hyndman
}

\begin{abstract}
This paper argues that distinct patterns of managing human displacement have emerged since the end of the Cold War. Using the case of Somali refugees in Kenya, the author illustrates what some of these strategies are: the deployment of "preventive zones" on the Somalian side of the border; the designation of prima facie refugee status which restricts Somali refugees to camps, and the reduction of opportunities for resettlement abroad. All of these serve to regionalize displacement in camps, for the most part, without providing a sustainable solution to the social and political crisis at hand.
\end{abstract}

\section{Précis}

Le présent article présente une argumentation selon laquelle des schémas distincts de gestion des déplacements humains se sont développés depuis la fin de la Guerre Froide. A partir du cas des réfugiés somaliens au Kenya, l'auteur illustre ce que certaines de ces stratégies sont: le déploiement de "zones préventives" sur la portion somalienne de la région frontalière; la désignation d'un statut de réfugié légitime restreignant les réfugiés somaliens à des camps, et la réduction des possibilités de rétablissement d̀ l'étranger. Toutes ces pratiques servent d̀ réduire les déplacement de populations principalement aux camps, sans fournir de solution viable da la crise sociale et politique en cours.

\section{[It is] not whether you are a refugee but where you are ... it's all a question of space and distance. Chief, Promotion of Refugee Law Section, UNHCR (personal interview, October 18, 1994)}

Jennifer Hyndman, Ph.D., is Assistant Professor of Geography, Arizona State University/West, Phoenix AZ, USA.

\author{
Doing political and accountable \\ protection work seems no longer the \\ fashion ... UNHCR is tempted to \\ engage in the politics of assistance, \\ the politics of solutions, or the \\ politics of prevention. \\ Guy Goodwin-Gill (1997)
}

Donor governments who fund displaced persons, whether they be refugees who have crossed international borders or uprooted people in their own countries, have increasingly urged United Nations organizations to assist them "at home" or in a first country of asylum nearby. Emerging national and ethnic divisions of power in the post-Cold War period have generated strategies of containment which serve to keep refugees and internally displaced people "over there," far from the borders of charitable donor countries in "the West." Since 1990, particular strategies have been employed to curb refugee flows through such measures as "preventive protection" and temporary refugee camps. The observation made above by a staff member from the Office of the United Nations High Commissioner for Refugees (UNHCR) suggests a deconstruction of the fixed category "refugee" and grounds human displacement in a contingent geographical context rather than in a legal definition which emphasizes the responsibilities and borders of states. This approach aims to be more inclusive in terms of who UNHCR assists, but it also has strategic value for the organization which has become one of the most powerful UN agencies in the current process of UN reform. Perhaps more importantly, UNHCR is responding to its donor governments who wish to maintain "space and distance" from the massive numbers of displaced persons; governments prefer interven- tions which provide assistance before potential refugees cross a border.

\section{Legacies of Colonialism, Cold War Proxies, and Current Trends?}

Refugees and displaced people are the human barometer of political stability, of justice and order in much of the world. (Winter 1993, 2)

Ethiopia and Somalia were central subjects in the Cold War race for advantageous positioning close to the precious resources of Western Asia, each country being a proxy for both American and Soviet interests at different times. In one sense, these countries were little more than Third World surfaces on which First and Second World superpowers poised themselves during this hostile period. The legacies of colonialism, in particular the problematic drawing of boundaries which divided ethnic Somalis in areas of Ethiopia and Kenya from the internationally recognized Somalian state, created another layer of conflict in the region. Fighting over the Ogaden area of Ethiopia, in which ethnic Somalis resided, provided yet another, even more regionalized, layer of rivalries between Ethiopia and Somalia.

The Organization of African Unity (OAU) Convention governing the Specific Aspects of Refugee Problems in Africa (1969) underscored the inviolability of national borders on the continent, borders which are admittedly artificial and in many cases outcomes of colonial rule dating back as far as the Berlin Conference in 1884-85. While most African governments are signatories to the OAU Convention, some critics argue that this inviolability should be reconsidered, and that borders be renegotiated as potential political solutions to current conflict and subsequent displacement in Africa (Zolberg and Callamard 1994). Recent 
UN interventions suggest that borders are being blurred; UN missions, such as UNOSOM II in Somalia, crossed once inviolable borders in the name of humanitarian protection and relief.

At the same time, the sovereign state is being interrogated. Its primacy in international politics is eroded by:

1) transnational flows of capital (Basch, Glick Schiller, and Szanton Blanc 1994);

2) increasing deterritorialization of nations vis-à-vis diasporic movement (Grewal and Kaplan 1994); and

3) the delegitimation of geopolitics, a formerly powerful, prevailing discourse of statehood.

If it ever did, nation no longer equals state as identities which correspond. Critics have argued that the language of international relations, which emphasizes strategic perspectives of conflict rather than ethnographic ones, is "state-centric" (Shapiro 1996). Likewise, geopolitics represents an increasingly outdated discourse of imperialism and state power which is uncritical of current constellations of power (O Tuathail 1996).

Refugees in this century grew out of events associated with the Cold War, as did the Office of UNHCR which was given an initial mandate to assist refugees in Europe generated during World War II. UNHCR's precursor organizations, however, emerged as early as 1921 as a response to involuntary migrants created after the Bolshevik Revolution (Rogers and Copeland 1993). UNHCR operates today on a scale unimaginable at its conception. In 1990, the agency had a budget of $\$ 544$ million and a staff of 2,400 . By 1996, the budget had grown to approximately $\$ 1.3$ billion and the staff to 5,000 (Frelick 1997). The advent of post-Cold War displacement and the responses it has generated have contributed to this transformation. While the United Nations High Commissioner for Refugees manages crises on a more massive scale than ever before and Western governments demonstrate unprecedented generosity in providing assistance, humanitarian responses have been expedient to a considerable extent-maintaining a distance between donor and displaced. "It has proven much easier to prevent the flow of refugees than to prevent the abuses, violence, and social inequities that cause them to flee" (Frelick 1993, 6). Refugee assistance and "preventive protection" - which underscores efforts to help displaced persons "at home" - serve to contain the problem of human displacement.

\section{Strategies of Containment: Preventing Protection, Negotiating Borders}

The word "protection" has become something of a term of art ... The word "refugee" is also a term of art in international law ... (Goodwin-Gill $1989,6,17$ )

"Preventive protection" is a term which describes a recent trend in managing transnational displacement. Increasingly the UNHCR has become involved in operations within countries in which people are displaced, often working in conflict zones. "Preventive protection" is part of a paradigm shift in refugee policy which occurred in the early 1990s (Frelick 1993). It belongs to a discourse which emphasizes the "right to remain" in one's home country over the former dominant discourse of the "right to leave." The "right to remain" was endorsed by the UN High Commissioner, Sadako Ogata, in the early 1990. UNHCR originally defined "preventive protection" as

the establishment or undertaking of specific activities inside the country of origin so that people no longer feel compelled to cross borders in search of protection and assistance. In this sense, for instance, action on behalf of the internally displaced can be defined as preventive protection, although the primary motive may be to address a genuine gap in protection rather than to avert outflow. Preventive protection in this sense may also include the establishment of "safety zones" or "safe areas" inside the country of origin where protec- tion may be sought. It relates therefore to the protection of nationals in their own country. (UNHCR 1992).

A politicized discourse of borders crossings and safe areas has replaced the term "preventive protection" but not the basic concept. This entire discourse is interesting because it gives rise to a new set of political spaces and management practices for forcibly displaced people. "Safe havens" for Iraqi Kurds, "zones of tranquillity" for returning Afghan refugees, "open relief centers" for would-be Sri Lankan refugees, and "safe corridors" to Muslim enclaves in Bosnia are all examples of this current trend and expressions of a post-Cold War discourse. The legitimacy of international borders is a related and current question among organizations managing displacement. In the foreword to a UNHCR document addressing the plight of internally displaced persons, the former Director of International Protection notes that people who are internally displaced on the "other" side of the border

have been called "refugees in all but name" ... Because they have not crossed an international boundary, the internally displaced have no access to the international protection mechanisms designed for refugees ... UNHCR finds it operationally untenable-as well as morally objectionable-to consider only the more visible facet of a situation of coerced displacement ... No two humanitarian crises are ever the same, and a global approach to such complex situations requires, if anything, finer tools of analysis and a larger arsenal of flexible responses. (UNHCR 1994a)

This is a compelling, sympathetic plea for inclusion on the part of the former head of the protection division. UNHCR has admitted, however, that crossing an international border to assist displaced people in their own country repeatedly-for instance in Iraq-may have unintended political consequences. Such a strategy may undermine the concept of the state, its authority, and most alarmingly, the obligation of the state itself to provide

Refuge, Vol. 16, No. 5 (November 1997) 
protection if an international agency will do it instead. While UNHCR recognizes this risk, it continues to expand its definition of "refugee" to include internally displaced people in selected cases. While space, distance, and geographical context may be increasingly relevant to UNHCR interventions and the refugee definitions of its formal mandate less important, state interests are effaced in this move to highlight the importance of particular spaces. By framing human displacement within specific geographical contexts, UNHCR questions the utility of its own abstract, admittedly outdated operational definitions, and proposes a potentially more situated and inclusive approach. It does so, however, by employing a set of "UN protected areas" and "preventive zones" that may be less than safe.

\section{The Case of Somalia}

The events that have transpired in Somalia, illustrate the idea of "preventive protection" in Africa. Containment strategies similar to those in Iraq and Bosnia have been tested in the Horn of Africa. In Southern Somalia, UNHCR created a "preventive zone" along the Kenyan border in order to slow the flow of potential refugees into Kenya and to encourage Somali refugees in Kenyan camps to return home. The Cross-Border Operation, as the initiative launched in 1992 was called, was also a strategy to empty the Kenyan camps after the Government of Kenya issued an ultimatum in January 1993 that all Somali refugees would be forcibly sent home. At the time, the U.S.led Operation Restore Hope was initiated. It sent tens of thousands of troops to Somalia on a humanitarian mission to assist the starving civilian population in December 1992. In May 1993, peacekeepers from UNOSOM II replaced those of Operation Restore Hope. UNHCR believed that the presence of these forces would also represent security to refugees living in Kenya and attract them back to Somalia. Some refugees did return home, but other Somali nationals left their war torn country for Kenya during the same period. In the end, the Cross-Border Operation did not meet its objectives, despite generous initial funding from donors.

"Safe havens" and "preventive zones" are expressions of an emerging post-Cold War geopolitical discourse and are strategic spaces to contain would-be refugees in their home countries. This strategy is endorsed by Western governments which fund UNHCR to execute the necessary emergency relief operations. UNHCR is revising its own traditional category of "refugee," recasting its protection mandate, and extending its reach inside the borders of countries at war where displaced people require assistance and safe-keeping. The efficacy and safety of these efforts are still in question after the U.S./UN intervention in Somalia. The massacre of civilians in Srebrenica in July 1995 and the killing of several thousand refugees in Kibeho camp in Rwanda in April 1995 also cast doubt.

\section{On the Kenyan Side of the Border}

Refugee camps constitute another strategy of containment with assistance. While camps are arguably a useful and acceptable short term emergency measure, the second-rate status accorded to refugees in these "temporary cities" is problematic. In Kenya, the vast majority of refugees are Somalis. At the end of 1996, there were approximately 185,000 refugees in Kenya; 150,000 were Somali refugees. Smaller numbers of Sudanese and Ethiopian refugees were also counted. UNHCR is responsible for refugees based on its Statute and in conjunction with the 1951 Convention and 1967 Protocol relating to the Status of Refugees which oblige signatory states to assist forcibly displaced migrants who meet specific criteria. Increasingly, a smaller and smaller proportion of refugees meet the formal Eurocentric post-World War II requirements of the Convention and Protocol (Hathaway 1991a). The Kenyan Government, despite being a signatory to the 1951 Convention and 1967 Protocol, is currently not considering asy- lum seekers for full, Convention refugee status. Accordingly, UNHCR has been called upon through its "good offices" to protect and assist refugees who do not meet the Convention or statutory definition; this residual group is designated prima facie refugees.

Usually prima facie designation is made on a group basis, rather than by individual assessment which is the norm for determining Convention status. In Kenya the vast majority of displaced Somalis and Sudanese fall into this ad hoc category of refugees. All prima facie refugees are required by the Kenyan Government to live in camps located in isolated border areas. Needless to say, not all of them do.

John Rogge $(1993,24)$ has described these authorized spaces for the displaced as "bleak and insecure holding camps along the Kenyan-Somali border." UNHCR is careful not to make the camps too attractive to potential refugees or other migrants by maintaining minimum education standards and other facilities, an approach that has been called "humane deterrence" (ibid.). The Kenyan camps illustrate how protection and assistance are inextricably linked to refugee containment and immobility. A historical discussion of politics along the KenyaSomalia border area is precluded here, except to say that the Northeast Province of Kenya-formerly known as Kenyan Somaliland-has been a hotbed of protest and repression since the time of Kenyan independence until 1967 when the Republic of Somalia renounced its goal of annexing the area. Since independence in 1963 until 1991, this region was under Government of Kenya "emergency rule." Many Kenyans of Somali origin have faced arbitrary arrest, harassment, and discrimination. Banditry and general insecurity continue to prevail in this region today.

Relief staff working in the camps, in my view, make the best of difficult situations with the interests of refugees in mind. The formal administrative practices employed, however, attest to authoritative structures and a 
quasi-military mode of operations that detract from this goodwill and hard work. Administration of the camps in this region involves a number of surveillance practices through which refugees are continually mapped, marked, and monitored. While these are certainly not the only techniques employed, the primacy of surveillance in the camps is revealed in the opening paragraph of the UNHCR's Country Operations Plan for 1995:

The reconciliation of data on the refugee population in Kenya has become a priority exercise of the Kenya programme during 1994. The Branch Office has addressed the intractable problem of discrepancies between feeding figures, registered numbers, and total populations, by camp site as well as by overall caseload and nationality, through physical headcounts and registration of refugees in the camps. These discrepancies are due to acts of refugee sabotage; double registration within camps and between camps; and inflation of the number of dependants on ration cards in a bid to maximize their entitlements to food and other relief assistance distributed in the camps. (UNHCR 1994c, 1)

The counting and coding of refugees in this passage is alarming. Nowhere is refugee assessment or need mentioned. Rather, displaced people are converted into suspicious subject populations, figures, and numbers.

The vast majority of refugees in Kenya have prima facie refugee status. They are entitled to assistance through the "good offices" of UNHCR but remain, in a practical sense, second-rate refugees. Their containment in camps and the suspension of basic rights which would allow them to find a more independent and self-sufficient livelihood define this second-rate status. Granted, they are given temporary safety and protection from refoulement, forcible return to the country from which they fled, but this is simply not good enough. While the movement of refugees outside the camps is officially prohibited, some are able to move to more strategic locations. This unauthorized movement of Somali refugees, in particular, annoys the Government of Kenya which then complains to UNHCR. Yet it is also a political statement that these authorities cannot simply "contain" the refugee problem.

\section{The Politics of Over There}

So far a number of parallel trends in the management of displacement have been identified. First, there is increasingly a two-tier refugee system in which fewer and fewer refugees meet the criteria for full Convention refugee status. Convention status has been "displaced;" in the Kenya case, by the discretionary group designation of prima facie refugees whose movement and entitlements are much more restricted. In Kenya, prima facie refugees are involuntary migrants contained in refugee camps "over there." Related to this trend is a shift in the locus of responsibility for displaced peoplewhether they are refugees or not-from individual states to international UN agencies, in particular to UNHCR which is funded by the very states that have traditionally received refugees in their countries. A senior staff member of an American agency based in the Kenyan camps said:

The donors are willing to pay them (UN agencies) off ... Africa is a sinkhole. You (UN agencies) take care of it; here's the money will eventually turn to you (UN agencies) take care of it; we' re not paying any more. Now we are in a grazing period where there is big money to be made (working in the aid industry). (Interview, January 1995)

The popularity of and sympathy for displaced peoples on the part of Western governments lies precisely in their location, "over there." As they approach "our" borders, they become "immigrants" and "foreigners" who face a less enthusiastic reception. The distance is also a discursive one: as long as one does not need to engage in face-to-face conversations with these unfortunate people whose plight is witnessed on television or through other media, their situation remains a tragedy.

\section{Looking ahead}

As the United Nations and several of its agencies turn fifty, change is imminent. The UN reform process is well underway, and all information to date suggests that UNHCR will become the lead agency for humanitarian crises. The safety, efficacy, and legality of containment strategies, such as the camps, is questionable in the context of human rights instruments and other international protocols. In Kenya, refugees are obliged to follow the laws of the land in which they are offered temporary asylum, yet they have none of the privileges of citizens or Convention refugees: to move, to work, to own property or have temporary access to land, and so on. While they are provided with protection and basic food, shelter, and medical services, the arrangement is recognized by all parties as a temporary one. It is also a relationship of dependency. For those refugees in Kenya who have lived in camps for as long as five years, this temporary solution has become increasingly permanent and unsatisfactory. Is five years enough? If the political situation in their own countries precludes repatriation in the short term, what is to be done?

These are exceedingly difficult questions for which answers are being sought and tested. Local integration in countries like Kenya is not an option. Voluntary repatriation is the best solution if it is available. How to measure safe conditions for voluntary repatriation remains a critical question. Forced repatriation is not a solution, though incidents of it are far too common (U.S. Committee for Refugees, 1997). As resettlement targets in the major refugeereceiving countries also decline, alternative solutions must be sought.

\section{Bibliography}

Basch, L., N. Glick Schiller, and C. Szanton Blanc. 1994. Nations Unbound: Transnational Projects, Postcolonial Predicaments, and Deterritorialized Nation-States. Langhorne, PA: Gordon and Breach.

Frelick, B. 1997 “Assistance Without Protection: Feed the Hungry, Clothe the Naked, 
and Watch Them Die." In World Refugee Survey 1997. Washington, DC: U.S. Committee for Refugees.

-. 1993. "Preventing Refugee Flows: Protection or Peril." In World Refugee Survey 1993. Washington, DC: U.s. Committee for Refugees.

Goodwin-Gill, G. 1989. "The Language of Protection." International Journal of Refugee Law 1, no. 1.

-.1997. "United Nations Reform and the Future of Refugee Protection." Commentary on the UN "Reflections" paper, posted on forced migration listserve, June 4.

Grewal, I., and C Kaplan. 1994. "Introduction: Transnational Feminist Practices and Questions of Postmodernity." In Scattered Hegemonies: Postmodernity and Transnational Feminist Practices, edited by I. Grewal and C Kaplan, 1-33. Minneapolis, MN: University of Minnesota Press.

Hathaway, J. C 1991a. The Status of Refugee Law. Toronto: Butterworths.

-. 1991b. "Reconceiving Refugee Law as Human Rights Protection." Journal of Refugee Studies 4, no. 2, 113-31.

Lawyers Committee for Human Rights. 1991. The UNHCR at 40: Refugee Protection at the Crossroads. New York: Lawyers Committee for Human Rights.
Massey, D. 1993. "Power-Geometry and a Progressive Sense of Place." In Mapping the Futures: Local Cultures, Global Change, edited byJ. Bird, B. Curtis, T. Putnam, G. Robertson, and L. Tickner, 5969. New York: Routledge.

Makinda, S. 1993. Seeking Peace From Chaos: Humanitarian Intervention in Somalia. Boulder and London: Lynne Rienner Publishers.

6 Tuathail, G. 1996. Critical Geo-politics. Min neapolis: University of Minnesota Press.

Rogge, J. 1993. "The Challenges of Changing Dimensions among the South's Refugees: Illustrations from Somalia." International Journal of Refugee Law 5, no. 1, 12-30. Oxford, UK: Oxford University Press.

Rogers, R., and E. Copeland. 1993. Forced Migration: Policy Issues in the PostCold War World. Medford, MA: Fletcher School of Law, Tufts University.

Shapiro, M. 1996. Violent Cartographies: Mapping Cultures of War. Minneapolis: University of Minnesota Press.

Suhrke,A.1994. "Towards a Comprehensive Refugee Policy: Conflict and Refugees in the Post-Cold War World." In Aid in Place of Migration? edited by W. R. Bohning and M.-L. Schloeter-Paredes, 1338. Geneva: ILO.
UNHCR.1992. "Report of the UNHCR Working Group on International Protection." Geneva: UNHCR.

-. 1993. The State of the World's Refugees: The Challenge of Protection. Toronto: Penguin.

-.1994a. UNHCR's Operational Experience with Internally Displaced Persons. Geneva: UNHCR.

-. 1994b. Note on International Protection, EXCOM 45th session, AI AC961 830.

-. 1994c. "Country Operations Plan Kenya." Nairobi: UNHCR.

U.S. Committee for Refugees. 1995. World Refugee Survey 1995. Washington, DC: USCR.

-.1997. World Refugee Survey 1997. Wash ington, DC: USCR.

Winter, R. 1993. "The Year in Review." In World Refugee Survey 1993. Washington, DC: U.S. Committee for Refugees.

Zolberg, A., and A. Callamard A.1994. "Dis placement-generating Conflicts and In ternational Assistance in the Horn of Africa." In Aid in Place of Migration? edited by W. R. Bohning and M.-L. SchloeterParedes, 101-17. Geneva: ILO. CJ

\title{
Refugee: Rights Report
}

\section{on a C'omparative Survey}

\author{
By James CrH thaway, and John A. Dent \\ Toronto: \\ 1995, pp. 82.
}

Are visa controls intended to keep refugees from reachin $\mathrm{g}$ an asylum country legal? Can asylum-seekers legitimately contest conditions of detention? At what point do refugees have the 19 ht to work, or to claim social assistance?

These are among the many issues addressed by Refugee Rights: Rep rt on a Comparative Survey, a ground-breaking analysis of the human rights of refugees around the world. Working in collaborationth thirty renowned legal experts from Europe, Africa, Asia, Oceania, North America, and Latin America, Professor James Hal Hath ay, Osgoode HaIl Law School, York University, and John Dent, Senior Research Associate, International Refugee Rights Prc international legal instruments that set the human rights of refugee today, Hathaway and Dent have produced a book as valuable to a

Project, Osgoode Hall Law School, York University, analyze the s. By grounding their analysis inreal-Hfe challenges facing refugees

Refugee Rights will provoke debate on the adequacy of the int concerned to counter threats to the human dignity of refugees.

ivists as to scholars.

Available from:

Centre for Refuge Studies, York University

Suite 333, York Lanes, 4700 Keele St., Toronto ON M3J

Fax: (416) 736-5837• Email: refuge@yorku.ca 